\title{
Synthesis of a synthetic analogue for the Sitophilus weevil aggregation pheromone and study on its hygienic and toxicological indexes
}

\author{
Gulnara SHAKIRZYANOVA ${ }^{1}$, Liliya ROMANOVA², Bahrom BABAEV ${ }^{1}$, Vladimir ABDUKACHAROV ${ }^{1}$, \\ Tulkun ISKANDAROV ${ }^{2}$, Sabina GAYIBOVA ${ }^{1 *}$
}

Received November 12, 2020; accepted March 16, 2021. Delo je prispelo 12. novembra 2020, sprejeto 16. marca 2021.

Synthesis of a synthetic analogue for the Sitophilus weevil aggregation pheromone and study on its hygienic and toxicological indexes

Abstract: The work was initiated to study hygienic and toxicological indices of a synthetic analogue for the Sitophilus weevil aggregation pheromone. The toxicity testing of 5-hydroxy-4-methyl-3-heptanone demonstrated its extremely low toxicity for the warm-blood animals, as compared to the one of the typical pesticides. The average lethal dose of the product per orally administered to the white mice was established to be $4375.0 \mathrm{mg} \mathrm{kg}^{-1} \mathrm{LD} 16$ and LD84 being $2225.0 \mathrm{mg} \mathrm{kg}^{-1}$ and $6550.0 \mathrm{mg} \mathrm{kg}^{-1}$, respectively. The average lethal dose for rabbits was $5900.0 \mathrm{mg} \mathrm{kg}^{-1} 5$-hydroxy-4-methyl-3-heptanone proved to have a mild skin and conjunctival irritant action, and equally mild functional cumulation. As to chronic toxicity, the acceptable daily dose of $4.3 \mathrm{mg} /$ person/d was calculated and scientifically substantiated. The odor threshold was determined at the dose ranging from 0.35 to $0.7 \mathrm{mg} \mathrm{l}^{-1}$ with the practical limit ranging from 0.35 to $1.5 \mathrm{mg} \mathrm{l}^{-1}$, taste sensation threshold was found at the dose ranging from 1.0 to $3.0 \mathrm{mg} \mathrm{l}^{-1}$ with the practical limit ranging from 3.0 to $7.0 \mathrm{mg} \mathrm{l}^{-1}$.

Key words: L-proline; aggregation pheromone; sitophilure; aldol condensation; pest insect, toxicological indexes
Sinteza sintetičnega analoga agregacijskega feromona in preučevanje higienskih in toksikoloških indeksov pri zatiranju žitnih žužkov (Sitophilus spp.)

Izvleček: Članek predstavlja raziskavo higienskih in toksikoloških indeksov pri sintezi agregacijskega feromona žitnih žužkov (Sitophilus spp.). Kot rezultat poskusov je bila izračunana dovoljena dnevna doza na osebo, in sicer $4,3 \mathrm{mg} /$ osebo/ dan; najmanjša izračunana doza za zaznavanje vonja je bila 0,42 $\mathrm{mg} \mathrm{l}^{-1}$, najmanjši vrednosti za okušanje in praktično uporabo sta bili določeni na ravni 1,44 in $3,3 \mathrm{mg} \mathrm{l}^{-1}$. Največja dovoljena in priporočena doza agregacijskih feromonov za žitne žužke v vodnih zbiralnikih je bila $0,4 \mathrm{mg} \mathrm{l}^{-1}$; pri čemer je bil vonj izbran kot omejujoč dejavnik za škodljivost; največja dovoljena koncentracija $\mathrm{v}$ zraku je bila določena kot $0,3 \mathrm{mg} \mathrm{m}^{-3}$ in največja dovoljena koncentracija $\mathrm{v}$ zraku v delovnem prostoru je bila določena kot $3,5 \mathrm{mg} \mathrm{m}^{-3}$. Rezultati raziskave so pokazali, da je imel 5-hidroksi-4-metil-3-heptanon blag dražilni učinek na koži in na sluznicah ter šibke akumulacijske vplive na splošno počutje.

Ključne besede: optične izomere; L-prolin; agregacijski feromon; žitni žužki; aldolna kondenzacija; toksikološki indeksi

1 Institute of Bioorganic Chemistry Uzbek Academy of Sciences, Mirzo Ulugbek Str., 83, Tashkent, Uzbekistan

2 Ministry of Health care Institute of Sanitation hygiene and occupational diseases, Oltin Tepa str., 325, Tashkent, Uzbekistan

* Corresponding author: gayibova.sabina@gmail.com 


\section{INTRODUCTION}

Production and reduction to practice of novel chemical, physical and biological products for pest management in agriculture are underway worldwide (Bohinc et al., 2020a). Search for novel highly efficient methods for pest control is driven by development of pesticide resistance in pest organisms caused by constant use of the products resulting in the uprise of the pesticide-resistant pest insect populations (Petrunya, 2011).

To prevent both quantitative and qualitative losses of agricultural products, the integrated pest management consisting of economically and environmentally feasible measures is needed. The system is based on the balanced combination of quarantine, preventive, physicalmechanical and biological measures, as well as of direct control to keep the proliferation of pest insects to reasonably safe level. The diversity of chemical products for crop protection suggests the increase of their toxic effects on living organisms making the search for environmental friendly protection products an urgent task.

Preventive and economic operations calling for high-level culture of storage and treatment of grain products at the granaries and grain mills comprise the backbone of the integrated test management. The fumigation or any other chemical treatment is supposed feasible in terms of grain infestation extent.

As natural bioregulators, the insect pheromones are thought to be promising in controlling the grain infestation extent at the granaries, maintaining the grain quality and avoiding the environmental pollution. The insect pheromones are known to exercise control over the pest insects resistant to existing insecticides or those requiring their multiple use (Trdan et al., 2019). This is especially true for covert living pests acquiring the pesticide resistance. The pheromone traps help bring to light the locations of pests with the lowest numbers when the visual inspection turns out inefficient. The synthetic analogues of the insect sex pheromones showed good results as tools for detection and monitoring of pest populations.

The synthetic chemicals, such as methyl bromide and aluminum phosphate were used in the largescale fumigations of granaries to control pests (Sousa et al., 2009). Furthermore, since larval and pupal instars develop within the rice and maize grains, any sustainable control strategy demands the timely and accurate monitoring of the prevalence of adult weevils (Ukeh et al., 2012). Sitophilus is a genus of weevils in the tribe Litosomini. Notable and the most menacing pest species include the rice weevil (S. oryzae, (Linnaeus, 1763), wheat weevil (S. granaries, Linnaeus, 1758), and maize weevil (S. zeamais, Motschulsky, 1858) (Ukeh et al., 2008), as well as the large mealworm, the cereal moth and other pests (Oe- hlschlager, 2016). The weevils of Sitophilus genus are the impactful pests of stored grains in tropical and sub-tropical regions, but they are common in Europe too (Bohinc et al., 2020b; Athanassiou \& Buchelos, 2001). They attack various stored products including maize, wheat, oats, barley, rye, and dried cassava roots, as well as processed food such as macaroni, noodles, biscuits, and cakes. The post-harvest losses due to storage pests, such as weevils Sitophilus pose major problems to food security in the world (Orlov, 2006). The losses of stock products due to the insect pests like this have long been a serious farmer problem around the world. Any human efforts and finances committed in the crop production are wasted. Sitophilus infest ripening standing crops immediately prior to harvest and in storage, causing damage by boring into the grains and eating the inner part, which reduces maize mass and quality in terms of consumption and germination (Zakladnoi et al., 2003). The synthetic pheromones were successfully used to control the curculionid beetles by mass trapping, as the pheromones attract both males and females (Adda et al., 2002).

The pheromone-based monitoring helps determine the time and necessity of chemical treatment, avoid use of pesticides and save the stored products ecologically pure. The study on toxicological and hygienic characteristics is indispensable. Our work was initiated to study the toxicity of a synthetic analogue for the Sitophilus weevil aggregation pheromone.

\section{MATERIAL AND METHODS}

All chemicals and solvents were purified by standard techniques. For thin-layer chromatography (TLC), Silufol silica gel plates (Sigma-Aldrich, Germany) and ethyl ether/hexane (1:1) system of eluents was used; the compound was visualized by irradiation with iodine vapor. Flash chromatography was performed using TLC Silica gel 60 F254 (Merck KGaA, Darmstadt, Germany) and ethyl ether/hexane (1:1) system of eluents. HPLC was performed using the Agilent 1100 Series HPLC System (USA) with a Daicel CHIRALPAK AS HPLC Analytical Column, $10 \mu \mathrm{m}$, ID $4.6 \mathrm{~mm}$ x L $250 \mathrm{~mm}$ - 20025, and Amylose tris [(S)--methylbenzylcarbamate] as a stationary phase coated on a $10 \mu \mathrm{m}$ silica support (Daicel Chemical Industries, Ltd. Japan); the mobile phase was acetonitrile (solvent $\mathrm{A}$ ) and $\mathrm{i}-\mathrm{PrOH}$ (solvent $\mathrm{B}$ ) in the gradient mode: $0-10 \mathrm{~min}, 2-10 \% \mathrm{~B}$ and $10-15 \mathrm{~min}$ $10 \% \mathrm{~B}$.

High-resolution mass spectra were recovered on 6420 Triple Quad LC/MS (Agilent Technologies, USA) with acetonitrile as an eluent in isocratic regime; the flow rate was $0.25 \mathrm{ml} \mathrm{min}{ }^{-1}$. The mass spectra were registered 
with negative ionization. Conditions were as follows: the scanning range was $50-2200 \mathrm{~m} / \mathrm{z}$, dehydrating gas consumption - $3 \mathrm{~min}^{-1}$, gas temperature $300{ }^{\circ} \mathrm{C}$, gas pressure on needle sprayer 20 psi, evaporator temperature $300^{\circ} \mathrm{C}$, tension on the capillary $-4000 \mathrm{~B}$.

\subsection{GENERATION OF ALDOL PRODUCT}

To generate the aldol product, propionaldehyde (3 $\mathrm{mmol}$ ) was added to a heterogeneous mixture of anhydrous chloroform $(10 \mathrm{ml}), 3$-pentanone $(0.06 \mathrm{~mol})$ and L-proline $(25 \%)$. The resulting mixture was stirred at the room temperature for $32 \mathrm{~h}$. The reaction mixture was treated with the saturated $\mathrm{NH}_{4} \mathrm{Cl}$ solution; the layers were separated, and the aqueous layers were extracted several times with ethyl acetate, dried with anhydrous $\mathrm{Na}_{2} \mathrm{SO}_{4}$ and evaporated. The pure aldol product was obtained by flash column chromatography with the yield of $74 \%$. HPLC was performed using ChiralPak AS - amylose tris [(S)-a-methylbenzylcarbamate] with $98 \% \mathrm{MeCN}$ and $2 \% \mathrm{i}-\mathrm{PrOH}$. Conditions were as follows: tR (major) $=$ $7.998 \mathrm{VP}, \mathrm{tR}($ minor $)=7.072 \mathrm{VV}$; $:$ R $-57.0722: 28.0855$, $\mathrm{tR}($ major $)=8.007 \mathrm{VP}, \mathrm{tR}($ minor $)=7.025 \mathrm{VV} ; \mathrm{S}^{*}: \mathrm{R}^{*}$ 43.4765 : 30.0490. MS [C8H16O2], $143[\mathrm{M}-\mathrm{H}+]-, 87$ [M - C3H5O]-.

\subsection{ACUTE TOXICITY}

Acute toxicity assessment was performed on the laboratory white mice. The animals' behavior, general health condition, terms for manifestation of intoxication sign and eventually death were the key criteria for the product's acute toxicity following its single administration to the animals. 2.3 SKIN IRRITANT ACTION

To assess the skin irritant action of the compound, its native sample was applied on the skin of laboratory white rats and animals were carefully monitored for any skin irritation signs.

\subsection{CONJUNCTIVAL IRRITATION}

To assess the conjunctival irritant action of the compound, 2 drops of the product were put in the conjunctival sac of one rat's eye, while the second one served as the control. The effects were registered in 1-4 hours and in 1,3 and 5 days.

\subsection{CUMULATIVE PROPERTIES}

To assess the cumulative properties of the compound, two groups of white $150-180 \mathrm{~g}$ rats of both sexes were selected for the experiment. The first group of rats received the product at the dose of $1 / 10 \mathrm{LD}_{50}$, the second one served as the control.

\subsection{CHRONIC TOXICITY}

Chronic toxicity was expressed as effective and noneffective doses.

\subsection{ASSESSMENT OF IMPACT IN THE ENVIRON- MENTAL SAMPLES}

To assess the impact of the compound in the environmental samples, its concentrations ranging from 0.17 to $8.0 \mathrm{~g} \mathrm{l}^{-1}$ were used.

\section{RESULTS AND DISCUSSION}

The aggregation pheromone of Sitophilus granarius and Sitophilus oryzae is produced by the insects in the period good to the development of a population, that is, where there is enough food and possibilities for reproduction, as well as appropriate environmental humidity and temperature. The food attractants and sexual stimulants cannot supersede the aggregation pheromone produced by both females and males. The rise and corn weevils were found to produce the aggregation pheromone in the form of $(4 \mathrm{~S}, 5 \mathrm{R})$ - hydroxy-methyl-3-heptanoneenantiomer (Fig.1) (Faustini et al., 1984).

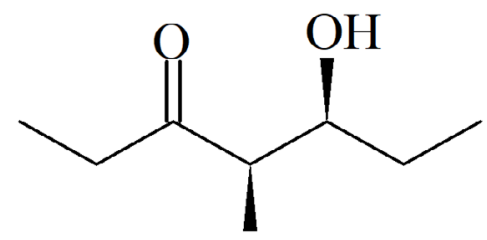

Figure 1: (4 S, 5 R) - hydroxy-methyl-3-hetanone

Diastereoisomers of 5-hydroxy-4-methyl-3-heptanone were identified as an aggregation pheromone produced by the male rice weevils (Sitophilus oryzae), and the maize weevils (S. zeamais). The compound has previously been reported as an aggregation pheromone produced by Rhinostomus barbirostris (Fabricius, 1775) (Coleoptera: Curculionidae, Fabricius, 1775) males. All three Sitophilus species belong to the subfamily Dryophthorinae, as $R$. barbirostris (Phillips et al., 1985; Ambrogi et 
al., 2008; Ambrogi et al., 2009). This compound is known to cause a behavioral response in the adult weevils. According to Ismuxambetov (2015), and the findings from our trials, there is the weevils' response to various combinations of enantiomers. According to that formula, the compound can exist in the form of 4 steric enantiomers<smiles>[R16]C([C@@H](O)CCI)[C@@H](O)CCI</smiles>

Figure 2: 4 steric enantiomers of $(4,5)$ - hydroxy- methyl-3-heptanone

(Fig. 2).

Unelius et al. resolved the four stereoisomers of 4-methyl-5-hydroxy-heptan-3-one by chiral gas chromatographic-mass spectrometric (GC-MS) analysis employing a CycloSil-B capillary column with the following elution order: (4R, 5S)-, (4S, 5R)-, (4R, 5R)-, (4S, 5S)-isomers (Unelius et al.,2012). Thus, to determine the absolute configuration of the Rhinostomus barbirostris pheromone, the mixture of all stereoisomers of synthetic sitophilure was also resolved in a CycloSil-B capillary column. The major component had the same retention time as the (4S, $5 \mathrm{R})$-isomer, and that of the minor pheromone component matched that of the (4S, 5S)-isomer (Unelius et al., 2012). The mixture of four stereoisomers of sitophilure has been synthesized previously by three different synthetic approaches. The first synthesis was reported even before the identification of this compound as a pheromone by coupling the lithium anion from 3-pentanone and propanal in $89 \%$ yield (Smith \& Levenberg, 1981).

Fauve et al. reported on the multigram synthesis as a more traditional approach with sodium hydroxide to generate the anion from 3-pentanone and subsequently to couple with propanal, giving hydroxyl-ketone in 46 $\%$ over-all yield (Fauve et al., 1984). The third method started by the alkylation of 3,5-heptanedione following by the reduction of one carbonyl group in $76 \%$ yield for two steps (Kalaitzakis et al., 2006).

Unelius et al. identified the minor component of Sitona discoideus Gyllenhal 1834 (Coleoptera : Curculionidae, Gyllenhal, 1834) pheromone, as (4S, 5S)5-hydroxy-4-methyl-3-heptanone by enantioselective GC analyses of the natural compounds on a modified $\beta$-cyclodextrine stationary phase in comparison with synthetic mixture of all four stereoisomers and derivatives obtained by enantiselective transesterification of the $(4 \mathrm{R}, 5 \mathrm{R})$ - and $(4 \mathrm{~S}, 5 \mathrm{R})$-isomers catalyzed by lipase from Candida antarctica (Goto, Sugiy. \& Iizuka) Kurtzman, M.J. Smiley, C.J. Johnson \& M.J. Hoffman (Unelius et al.,2012). We have synthetized diastereomers of 5-hydroxy-4-methyl-3-heptanone by means of different methods. The corresponding ketol has been obtained by aldol condensation between diethylketone and propylaldehyde; the asymmetric catalytic aldol reaction was carried out according to interaction of 3-pentanon and propylaldehyde by L-proline initiation, as well (Shakirzyanova et al., 2018). In the present work, in the conditions of aldol condensation between 3-pentanon and propyl aldehyde, we have obtained the corresponding ketol -

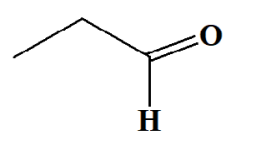<smiles>CCC(=O)C[18F]</smiles>

\section{1,2 \\ 1. $\mathrm{CH}_{3} \mathrm{OH}$ 2. $\mathrm{KOH}$}<smiles>CCC(=O)C(C)C(O)CC</smiles>

Figure 3: The synthesis of 5-hydroxy-4-methyl-3-heptanone 
5-hydroxy-4-methyl-3-heptanone, an aggregation pheromone of granary and rice weevils (Fig. 3).

The ratio of $\mathrm{R}^{\star} \mathrm{S}^{\star}$ and $\mathrm{R}^{\star} \mathrm{R}^{\star}$ diastereomers was about 1:1. For aldol condensation we used 1.33 M 3-pentanon, $0.33 \mathrm{M}$ propylaldehyde and $7 \% \mathrm{KOH}$ solution in methanol with reaction temperature $15^{\circ} \mathrm{C}$ and yield being 50 $\%$. The findings from the preliminary studies taken into account, we performed the synthesis of the weevil aggregation pheromone adding aldol in the presence of $\mathrm{L}$ proline as a catalyst.

Organocatalysis is a promising sphere in both organic and bioorganic chemistry. It is the way to get organic compounds from achiral predecessors in the presence of a small number of asymmetric metal-free organic molecules acting as the chiral inductors, but not getting involved into the process (Demyanovich et al., 2001).

Most enzymatic transformations have a synthetic counterpart. Often though, the mechanisms by which natural and synthetic catalysts operate differ markedly. The catalytic asymmetric aldol reaction as a fundamental $\mathrm{C}-\mathrm{C}$ bond forming reaction in chemistry and biology is an interesting case in this respect. Chemically, this reaction is dominated by approaches that utilize preformed enolate equivalents in combination with a chiral catalyst (Denmark et al., 1998). Some of them, according to their activity and enantioselectivity, do not act as metal-complex catalysts. The aldol reaction is widely regarded to be one of the most important carbon-carbon bond-forming utilized in organic synthesis (List et al., 2010). The catalytic enantioselective carbon-carbon bond-forming is a significant problem in the synthesis of biologically active substances. The chiral amino acid catalysts have wide usage for most powerful enantioselective reactions (Hayashi, 2005). In nature, that reaction goes through the action of aldolases (types I and II). In the laboratory con- ditions, their effect could be simulated by natural amino acids, some chiral amines and small peptides. Amino acids use a fundamentally different strategy and catalyze the direct aldolization of two unmodified carbonyl compounds (Ramachandran et al., 1996). Many enantioselective aldol-krotonic reactions catalyzed by L-proline; and the reaction is performed via an enamine intermediate complex. The L-proline-catalyzed aldolyzation can be initiated with different aldehydes.

The low price and wide spread availability in two enantiometric forms are among the advantages of L-proline as a catalyst. Proline, as a small molecular compound, can be used for direct intramolecular aldol condensation (List et al., 2010), and many reactions with proline can be performed in industrial production. It is also important that the reaction be conducted in the room conditions without inert medium, requiring no transformations of the carbonyl substrate; that is, with neither deprotonation nor stimulation during reaction. Moreover, the catalyst is water soluble and can be easily extracted.

Here, we describe structure-activity relationships of proline catalysts of direct assymmetric aldol addition reactions, as well as the findings from study on the reaction mechanism. As the result of interaction of 3-pentanone, as a donor and propion aldehyde, as an acceptor into the presence of L-proline, the direct asymmetric aldolization has been performed. The L-proline-catalyzed asymmetric aldolization requires anhydrous solvents. The reaction was performed via an enamine intramolecular complex. As it is, the intramolecular complex of direct asymmetric aldol reaction is the enamine formation involving Lproline and appropriate 3-pentanone, a donor-substrate. Thereafter, the acceptor's carbonyl-group from propionaldehyde attacks the enamine intramolecular complex;

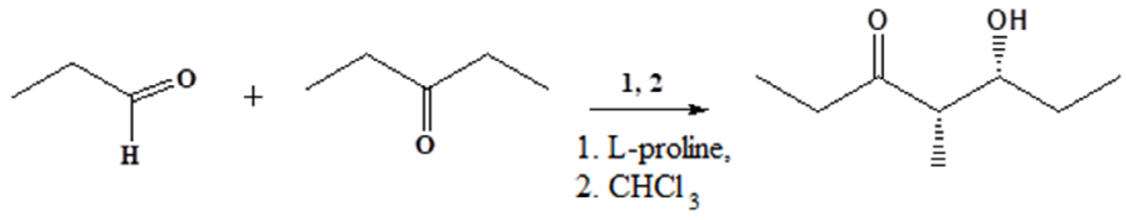

Figure 4: Synthesis of the L-proline-catalyzed aldol product 

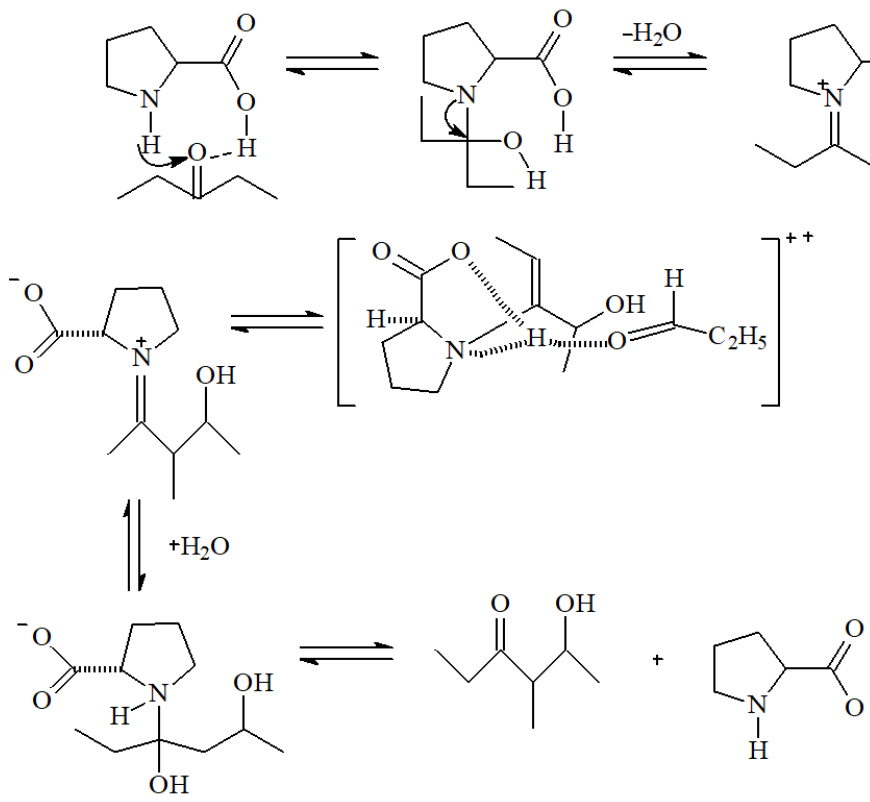

Figure 5: Proposed enamine mechanism of the proline-catalyzed asymmetric aldol reaction

the process is completed by formation of an aldol product (Fig. 4).

After separation, the reaction product was analyzed by HPLC (ChiralPak ${ }^{\otimes}$ AS - Amylose tris [(S)- $\alpha$ methylbenzylcarbamate] with $98 \% \mathrm{MeCN}$ and $2 \%$ i$\mathrm{PrOH}$.

In addition, we have analyzed the component consisting of (4S, 5S)-4-methyl-5-hydroxy-heptan-3-one by the electrospray ionization mass spectrometry (ESI-MS) with the registration of the mass spectra with negative ionization.

Thus, we have synthesized isomers of (5S, 4S)--5methyl-4-hydroxy-3-heptanone, an aggregation pheromone of rice, granary and maize weevils. The interaction of 3-pentanone and propionaldehyde in the aldol condensation reaction was realized in the presence of L-proline. Chloroform was more suitable solvent for the cross-coupling. The aldolization was performed via the enamine intramolecular complex. Changing terms of reaction couldn't influence the product's of enantio selectivity (Fig. 5).

Acute toxicity assessment revealed that animals snorting and cheeping were among the typical clinical symptoms. They started rushing around the cages; the excitement was followed by the motor activity reduction; the breath was shallow. The animals died within the first experimental day. The average lethal dose of the product per orally administered to the white mice was established to be $4000.0 \mathrm{mg} \mathrm{kg}^{-1} ; \mathrm{LD}_{16}$ and $\mathrm{LD}_{84}$ being 2600.0 and $5300.0 \mathrm{mg} \mathrm{kg}^{-1}$, respectively. The dose range from 1000.0 to $7000.0 \mathrm{mg} \mathrm{kg}^{-1}$ was used to be per orally administered to the white rats. Statistical processing of the data allowed establishing the average lethal dose to be 4375.0 $\mathrm{mg} \mathrm{kg}{ }^{-1} ; \mathrm{LD}_{16}$ and $\mathrm{LD}_{84}$ being $2225.0 \mathrm{mg} \mathrm{kg}^{-1}$ and 6550.0 $\mathrm{mg} \mathrm{kg}{ }^{-1}$, respectively. According to Deichmann (1943), the average lethal dose for rabbits was $5900.0 \mathrm{mg} \mathrm{kg}^{-1}$. In accordance with the Uzbekistan Sanitary Regulations and Standards for Classification of Pesticides by Toxicity and Hazard (Iskandarov et al., 2015), as a low-toxic compound 5-hydroxy-4-methyl-3-heptanone can be ranged in the IV class of hazard.

Following the 4-hour exposure, as well as in 1 and 16 hours after single exposure the dermal response was registered. At application the strong odor of the product made the animals sneeze and snort. The application removed and washed out, insignificant hyperemia of the chosen areas was observed to preserve after 1 hour and to be less marked one. In 24 hours after the experiment started, the residual hyperemic effect persisted; neither skin cracks nor peeling was registered. No signs of skin irritant action were found on the 2nd day of experiment. The findings could be the evidence for weak skin irritant action of the compound under study.

Conjunctival irritation results showed that following the administration, the rats cheeped and snorted trying to scratch the eye. In an hour, insignificant conjunctival hyperemia could be registered; the palpebral fissure was narrowed. In 3 hours, the signs of irritation subsided, while mild hyperemia and the palpebral fissure's narrowness persisted. In 24 hours, the palpebral fissure's size 
was within normal limits; hyperemia was unregistered. During the whole period of assessment (up to 5 days), no signs of irritation could be seen to confirm the mild conjunctival irritation.

Evaluation of the cumulative properties showed that during the experiment no animals died; any calculations of the cumulation factor failed. But manifestation of some intoxication signs suggested the mild functional cumulation. Minimum effective and non-effective doses of the compound under study were established to be 18.0 and $3.6 \mathrm{mg} \mathrm{kg}^{-1}$, respectively. The acceptable daily dose of $4.3 \mathrm{mg} /$ person/d was calculated and scientifically substantiated.

According to environmental impact assessment data the sample was found to give a specific indescribable smell and bitter taste tang to water. The odor threshold (1 point) was determined at the dose ranging from 0.35 to $0.7 \mathrm{mg} \mathrm{l}^{-1}$ with the practical limit ranging from 0.35 to $1.5 \mathrm{mg} \mathrm{l}^{-1}$, taste sensation threshold was found at the dose ranging from 1.0 to $3.0 \mathrm{mg} \mathrm{l}^{-1}$ with the practical limit ranging from 3.0 to $7.0 \mathrm{mg} \mathrm{l}^{-1}$.

\section{CONCLUSION}

As it can be seen, negligible effective doses and the environmental safety are typical of pheromones used to assess the phytosanitary conditions, localization and eradication of pest centers and to reduce the numbers of quarantine pest insects. In contrast to pesticides (Abasov et al., 2015), the pheromones' effects are not toxic and environmentally safe. We have synthesized isomers of (5S, 4S)--5-methyl-4-hydroxy-3-heptanone, an aggregation pheromone of rice, granary and maize weevils. Our toxicity testing of 5-hydroxy-4-methyl-3-heptanone demonstrated its extremely low toxicity for the warm-blood animals, as compared to the one of the typical pesticides.

The average lethal dose of the product per orally administered to the white mice was established to be 4375.0 $\mathrm{mg} \mathrm{kg}{ }^{-1} ; \mathrm{LD}_{16}$ and $\mathrm{LD}_{84}$ being $2225.0 \mathrm{mg} \mathrm{kg}^{-1}$ and 6550.0 $\mathrm{mg} \mathrm{kg}^{-1}$, respectively. According to D. LeBlanc, the average lethal dose for rabbits was $5900.0 \mathrm{mg} \mathrm{kg}^{-1}$. 5-hydroxy4-methyl-3-heptanone proved to have a mild skin and conjunctival irritant action, and equally mild functional cumulation. As to chronic toxicity, the acceptable daily dose of $4.3 \mathrm{mg} /$ person/d was calculated and scientifically substantiated. The odor threshold was determined at the dose ranging from 0.35 to $0.7 \mathrm{mg} \mathrm{l}^{-1}$ with the practical limit ranging from 0.35 to $1.5 \mathrm{mg} \mathrm{l}^{-1}$, taste sensation threshold was found at the dose ranging from 1.0 to 3.0 $\mathrm{mg} \mathrm{l}^{-1}$ with the practical limit ranging from 3.0 to $7.0 \mathrm{mg}$ $1^{-1}$.

As a part of the integrated pest management, the pheromone-based monitoring is successfully used to control the most menacing Sitophilus and Rhinostomus barbirostris species in Uzbekistan.

\section{ACKNOWLEDGMENTS}

The work was supported by Uzbekistan Ministry of Innovation (grant ITD-9)

\section{REFERENCES}

Abasov, M., Atanov, M., Kuzina, N., Kuzina, A., \& Ponomarev, V. (2015). Program for the identification of quarantine pests in the Russian Federation using pheromone and color traps in areas of greatest pest risk for 2016-2018 (In Russian). https:// vniikr.ru/files/contact/pr_16_18.pdf

Adda, C., Borgemeister, C., Biliwa, A., Meikle, W., Markham, R., \& Poehling, H. (2002). Integrated pest management in post-harvest maize: A case study from the Republic of Togo (West Africa). Agriculture, Ecosystems \& Environment, 93(1-3), 305-321. https://doi.org/10.1016/s01678809(01)00344-9

Ambrogi, B. G., \& Zarbin, P. H. (2008). Aggregation pheromone in Sternechus subsignatus (Coleoptera: Curculionidae): olfactory behaviour and temporal pattern of emission. Journal of Applied Entomology, 132(1), 54-58. https:// doi.org/10.1111/j.1439-0418.2007.01240.x

Ambrogi, B. G., Vidal, D. M., Zarbin, P. H., \& Rosado-Neto, G. H. (2009). Aggregation pheromone in Curculionidae (Insecta: Coleoptera) and their taxonomic implication. Quimica Nova, 32(8), 2151-2158. http://dx.doi. org/10.1590/S0100-40422009000800029

Athanassiou, C.G. \& Bucheloc, G.Th. (2001). The presence of Sitophilus zeamais Motschulsky (Coleoptera: Curculionidae) in Greece: distribution and food preferences. Annales of Benaki Phytopathological Institute, 19, 140-144.

Bohinc, T., Horvat, A., Ocvirk, M., Košir, I. J., Rutnik, K., \& Trdan, S. (2020a). The first evidence of the Insecticidal potential of plant powders from invasive alien plants against rice weevil under laboratory conditions. Applied Sciences, 10(21), 7828. https://doi.org/10.3390/app10217828

Bohinc, T., Horvat, A., Andrić, G., Golić, M. P., Kljajić, P., \& Trdan, S. (2020b). Natural versus synthetic zeolites for controlling the maize weevil (Sitophilus zeamais)-like Messi versus Ronaldo? Journal of Stored Products Research, 88, 101639. https://doi.org/10.1016/j.jspr.2020.101639

Deichmann, W.B., LeBlanc, T.J. (1943) Determination of the approximate lethal dose with approximately six animals. The Journal of Industrial Hygiene and Toxicology, 25, 415-417.

Demyanovich, V., Shishkina, I., \& Zefirov, N. (2001). Catalyzed asymmetric dialkylzinc addition to benzaldehyde in the presence of new chiral ligands $\delta$-(1-phenethyl) aminoalcohols. Chirality, 13(8), 507-509. https://doi.org/10.1002/ chir.1068

Denmark, S. E., Stavenger, R. A., \& Wong, K. T. (1998). A notable exception is Denmark's chiral Lewis base-catalyzed 
Mukayama-type aldol reaction. Journal of Organic Chemistry, 63(4), 918-919. https://doi.org/10.1021/jo972168h

Faustini, D. L., Giese, W. L., Phillips, J. K., \& Burkholder, W. E. (1984). Aggregation pheromone of the male granary weevil, Sitophilus granarius (L.). Journal of Chemical Ecology, 8(4), 679-687. https://doi.org/10.1007/bf00988309

Fauve, A., \& Veschambre, H. (1984). Use of biological systems for the preparation of chiral molecules IV: A two-step chemoenzymatic synthesis of a natural pheromone (4r, $5 \mathrm{~s})$ (-)-4-methyl 5-hydroxy heptan 3-one, sitophilure. Tetrahedron Letters, 28(42), 5037-5040. https://doi.org/10.1016/ s0040-4039(00)96689-9

Hayashi, Y. (2005). Recent progress in the asymmetric organocatalysis. ChemInform, 36(41), 464-477. https://doi. org/10.1002/chin.200541296

Iskandarov, T., Iskandarova, G., \& Romanova, L. (2015, September 22). Sanitary and preventive instruction of the Republic of Uzbekistan № 0321-15. Hygienic classification of pesticides by toxicity and hazard. Ministry of Health of the Republic of Uzbekistan. https://www.minzdrav.uz/pdf/ read.php? $\mathrm{f}=48050$

Ismuxambetov, J. D. (2015). Stock pest control in Kazakhstan. Bulletin of Science of the Kazakh Agrotechnical University named after S. Seifullin (interdisciplinary), 2(85), 4-12.

List, B., Lerner, R. A., \& Barbas III, C. F. (2010). Proline-catalyzed direct asymmetric aldol reactions. Journal of the American Chemical Society, 31(22), 2395-2396. https://doi. org/10.1002/chin.200022046

Oehlschlager, A. C. (2016). Palm weevil pheromones - discovery and use. Journal of Chemical Ecology, 42(7), 617-630. https://doi.org/10.1007/s10886-016-0720-0

Orlov V. N. (2006). Insect-pests of grain-crops. Moscow: Printing City, $102 \mathrm{p}$.

Petrunja, E. V. (2011). Grain stock pest control measures: classic and new (in Russian). Pest Management, 2(78), 20-23.

Phillips, J. K., Walgenbach, C. A., Klein, J. A., Burkholder, W. E., Schmuff, N. R., \& Fales, H. M. (1985). (R*, $\left.\mathrm{S}^{\star}\right)$-5-hydroxy4-methyl-3-heptanone male-produced aggregation pheromone of Sitophilus oryzae (L.) and S. zeamais Motsch. Journal of Chemical Ecology, 11(9), 1263-1274. https://doi. org/10.1007/bf01024114

Ramachandran, P., Xu, W., \& Brown, H. C. (1996). Contrasting steric effects of the ketones and aldehydes in the reactions of the diisopinocampheyl enolborinates of methyl ketones with aldehydes. Tetrahedron Letters, 37(28), 4911-4914. https://doi.org/10.1016/0040-4039(96)00969-0
Shakirzyanova, G. S., Babaev, B. N., Elmuradov, B. G., Mamadrahimov, A., \& Abdukacharov, V. S. (2018). Synthesis of optical active isomer - sitophilure - aggregetion pheromone of rice (Sitophilus oryzae L.), grainary (S. granarius L.) and maize. Bulletin of Science and Education, Moscow, 9(33), 15-21.

Smith, III, A. B., \& Levenberg, P. A. (1981). Oxidation of $\beta$-hydroxyketones and esters: A convenient synthesis of 1, 3-Diketones and $\beta$-ketoesters. Synthesis, $(07,567-$ 570. https://doi.org/10.1055/s-1981-29532

Sousa, A., Faroni, L., Pimentel, M., \& Guedes, R. (2009). Developmental and population growth rates of phosphine-resistant and -susceptible populations of stored-product insect pests. Journal of Stored Products Research, 45(4), 241-246. https://doi.org/10.1016/j.jspr.2009.04.003

Trdan, S., Čuk, J., Poženel, A., Bavcon Kralj, M., Rot, M., Carlevaris, B., Žežlina, I., Vidrih, M., Laznik, Ž., \& Bohinc, T. (2018). Field testing of different synthetic attractants for mass trapping of common European cockchafer (Melolontha melolontha [L.], Coleoptera, Scarabaeidae) adults. Acta Agriculturae Scandinavica, Section B - Soil \& Plant Science, 69(2), 174-180. https://doi.org/10.1080/09064710.2018.152 4020

Ukeh, D. A., \& Udo, I. A. (2008). Analysis of insect populations in stored crops in Cross River state, Nigeria. Global Journal of Pure and Applied Sciences, 14(1), 31-36. https://doi. org/10.4314/gjpas.v14i1.16769

Ukeh, D. A., Umoetok, S. B., Bowman, A. S., Jennifer Mordue (Luntz), A., Pickett, J. A., \& Birkett, M. A. (2012). Alligator pepper, Aframomum melegueta, and ginger, Zingiber officinale, reduce stored maize infestation by the maize weevil, Sitophilus zeamais in traditional African granaries. Crop Protection, 32, 99-103. https://doi.org/10.1016/j. cropro.2011.10.013

Unelius, C. R., Park, K., McNeill, M., Wee, S. L., Bohman, B., \& Suckling, D. M. (2012). Identification and electrophysiological studies of (4s, 5s)-5-hydroxy-4-methyl-3-heptanone and 4-methyl-3, 5-heptanedione in male Lucerne weevils. Naturwissenschaften, 100(2), 135-143. https://doi. org/10.1007/s00114-012-1003-4

Zakladnoi, G. A., Sokolov, E. A., Kogteva, E. F., \& Chirkov, A. M. (2003). A guide to pests of grain stocks and "Expanse" as a means of combating them. Moscow: Publishing House of Moscow State Educational Institution, 107 p. 